\title{
Research Status on Suaeda heteroptera Kitag
}

\author{
Jing Ji \\ Department of Marine Ecology, College of Marine Life Sciences, Ocean University of China \\ Qingdao, Shandong Province, China \\ E-mail: j1xj88352@163.com
}

Received: March 2, 2015 Accepted: May 15, 2015 Published: July 25, 2015

doi:10.5296/ast.v3i2.8053ＵRL: http://dx.doi.org/10.5296/ast.v3i2.8053

\begin{abstract}
The utilization value, morphological characteristics, biological characteristics, mechanism of salt tolerance, soil-repairing function, degradation, planting and breeding technology, development prospect and significance of Suaeda heteroptera Kitag were described, and the attentions which should be paid in its study and utilization in the future were put forward.
\end{abstract}

Keywords: Utilization value, Morphological characteristics, Biological characteristics, Degradation, Planting and breeding technology, Suaeda heteroptera Kitag 


\section{Introduction}

Nearly one billion hectares of land are salt-affected throughout the world, which account for about $25 \%$ of the whole land area. In China, various types of salt-affected land's area are about 34.6 million hectares (Zhang et al., 2007). Excessive soil salinity can cause water deficit, ion toxicity, and nutrient deficiency leading to molecular damage and even plant death (Wang et al., 2007). While the halophytes can be very tolerant of salt, complete their life cycles normally under salt stress and are very abundant in nature. Growing salt-tolerant plants in saline soil, on one hand, these halophytes have the potential to be used as vegetable, forage and possess certain economic value; on the other hand, it's also an effective measure to soil reclamation. Therefore, the exploitation of halophytes has lately been receiving more attention (Khan et al., 2006). S. heteroptera is one of the most important halophytes in China. Researches indicated that $S$. heteroptera with high nutrient value is a pioneer plant of saline soil due to its special physiological characteristics and morphological structure. It is also a kind of plant very strong in salt tolerance and can decrease the salt content of saline soil. Its soil ameliorating effect on coastal saline soil is significant (Lin et al., 2005; Li et al., 2007). Various aspects of $S$. heteroptera were reviewed, which could provide reference material and scientific basis for the further exploitation and utilization, environmental evaluation and environmental protection in intertidal zone and saline areas.

S. heteroptera, belonging to Suaeda of the Chenopodiaceous family, is an annual herbaceous plant and also known as Suaeda salsa L. It is native to salinity soil and adapted to the high salinity region in the Asia and Europe. It always occurs in lakeside, desert, river and coastal regions and widely distributes in Hebei, Shanxi, Qinghai, Zhejiang, Jiangsu and Shandong province in China.

\section{Utilization Value}

$S$. heteroptera is a potential wild plant resource, which has a high value for development. $S$. heteroptera has important economical value because it richly contains the nutrition, medicine and other ingredients. It has a broad prospect and huge potential in manufacturing health care edible oil, health care medicine and high-quality cosmetics. Modern medical researches have found that it has the effects of reducing blood sugar, dilating blood vessels, preventing and curing heart disease and enhancing human immunity. The fresh branches of $S$. heteroptera are widely consumed as a favorable vegetable due to its sufficient nutrient components, including 7 vitamins, 18 essential amino acids, 5 essential elements and other antioxidant ingredients (Wang et al., 2007). Its seeds contain approximately $40 \%$ oil, rich in unsaturated fatty acids, which can be easily converted to chemical compounds for industrial and pharmaceutical use (Zhao 1998). State Oceanic Administration of China has produced conjugated linoleic acid with the oil of $S$. heteroptera seed. $S$. heteroptera is also a potential feedstock for some production such as bio-ethanol (Li et al. 2013).

Planting S. heteroptera can affect water content in soil, increase humidity in the air, and lower down temperature and wind speed, as well as decrease evaporation of water in soil (Zhao et al., 2002). The development of $S$. heteroptera is conductive to the environment virescence and vegetation restoration of saline environment, then will prevent soil and water loss to maintain and rescue the ecological environment which is on the verge of destruction. $S$. heteroptera can effectively reduce the soil salinity, increase soil organic matter content, improve the content of N、P、K in the soil. Therefore, S. heteroptera has remarkable effects for improving the ecosystem of coastal saline soil. It also would play an important role in 
exploiting coastal tideland resource, developing coastal tideland agriculture and protecting the ecological environment.

The natural $S$. heteroptera community can come into being beautiful "red carpet" landscape, which is an important ecological tourism resource. The "red carpet" not only has ornamental value but also is the paradise of some precious species. Autumn is the mature season of the "red carpet" seeds. The seeds can provide plenty of food for precious birds and even create a favorable breeding habitat for Saunders' Gull, red-crowned crane and other precious species. Therefore, $S$. heteroptera has very high economic value, ecological value and landscape value.

\section{Morphological Characteristics}

High leaf or stem water content, succulence, is an adaptive feature, which contributes to the regulation of internal ion concentrations in many halophytic species (Short \& Colmer, 1999). $S$. heteroptera is a popular halophyte and has the typical shape and structure characteristics of halophytes with small, linear and succulent leaves. All of the mesophyll is the aqueous tissue. Leaf's epidermis cuticle is developed. Length and width of leaves are $10 \mathrm{~mm}-30 \mathrm{~mm}$ and $2 \mathrm{~mm}-3 \mathrm{~mm}$, respectively. The palisade tissue and aqueous tissue of its leaves are very developed, and that's the result of adaptation to resistance to high-salt and drought stresses. Its stems are erect with some vertical red stripes. And its branches are slender. The shoots of $S$. heteroptera plants are green in early growth stage, but red-violet in late autumn. The plant height is about $20 \mathrm{~cm}-80 \mathrm{~cm}$ and can be up to $120 \mathrm{~cm}$ after well cultivation. The annual capacity of the stems and leaves of $S$. heteroptera is about $0.45-0.9$ dry tons per hectare. Song and the others had carried on the comparative study of four kinds of pollen morphology of $S$. heteroptera under different habitat conditions, and the results indicated that the pollen of $S$. heteroptera is spherical; pollen size is $15.4 \mu \mathrm{m}-24.0 \mu \mathrm{m}$; the number of aperture is $46-65$; the diameter of the aperture is $3.1 \mu \mathrm{m}-5.4 \mu \mathrm{m}$. The surface of pollen grain is smooth. There are many small granular protuberances distributing on the surface of pollen grain and the aperture (Cui et al. 2009). S. heteroptera produces dimorphic seeds (soft brown seeds and hard black seeds). The seeds are so small that thousand seed weight is about $2.7 \mathrm{~g}$. The seed production of wild $S$. heteroptera is low, while the yield can increase by 3-4 times after artificial cultivation and physical processing.

\section{Biological Characteristics}

S. heteroptera grows in temperate saline areas of China(Li et al., 2005), where the dominant ions in soil are $\mathrm{Na}^{+}, \mathrm{Mg}^{2+}, \mathrm{Cl}^{-}$and $\mathrm{SO}_{4}{ }^{2-}$ (Wang, 1993). The temperature suitable to growth of $S$. heteroptera is $20 \square \sim 30 \square$, and the sunshine percentage suitable to growth is above $60 \% S$. heteroptera starts growing in Spring when the temperature is above $8 \square$. After germination in spring, the seedling growth is inhibited because of the temperature of the saline soil increasing slowly, and the biomass increases sluggishly too. After the middle of May, the peak period of growth, temperature stabilizes more than $20 \square$. During this period, the plant height can increase $40 \mathrm{~cm}-50 \mathrm{~cm}$. After flowering, the plant growth speed slows down again, and the plant water content is reducing while the dry weight is increasing. Seeds of $S$. heteroptera germinate in late April, plants flower from July onwards, while seeds start to mature in late October and die in late November. S. heteroptera has strong stress resistance, especially prominent salinity resistance. It can survive in $4.3 \%$ sea water. It is a pioneer plant in the saline soils and can develop normally and complete life cycle in saline environment. Some researches had shown that the solube salt content suitable to growth of $S$. heteroptera was $10 \mathrm{~g} \mathrm{~kg}^{-1}-16 \mathrm{~g} \mathrm{~kg}^{-1}$. S. heteroptera can grow in the ocean and swamp zone, even can 
survive in the desert and arid grassland zone, which indicates that $S$. heteroptera possesses the advanced characteristics of cold-tolerance, drought-tolerance, salt-tolerance and strong adaptability.

\section{Mechanism of Salt Tolerance}

The direct impact of salt on plant growth could be due to the decrease in osmotic potential in the soil solution, the toxicity caused by excessive $\mathrm{Na}^{+}$and $\mathrm{Cl}^{-}$in plant cells, and the nutrient imbalance in plant tissues (Evelin et al., 2009). Salt resistance of plants to a great degree depends on ionic metabolization. Analyses have shown that the shoot and root salt content of S. heteroptera can be $23 \%-27 \%$ and $10 \%-12 \%$ of dry weight, respectively (Jia et al., 1977). Zhang (2002) reported that $\mathrm{Na}^{+}$and $\mathrm{Cl}^{-}$content of leaves and roots increased with the increasing $\mathrm{NaCl}$ concentrations, and had similar accumulating tendency. $\mathrm{Na}^{+}, \mathrm{Cl}^{-}$and the total ions content in roots were evidently lower than that in leaves under salt treatments, and a characteristic adaptability to salt environment that a large number of ions $\left(\mathrm{Na}^{+}, \mathrm{Cl}^{-}\right)$were preferentially accumulated in leaves was suggested (Zhang, 2002). Aboveground parts accumulates lots of ions, which is beneficial to increase the osmotic potential difference between aboveground parts and root, promote the water transportation from root to aboveground parts, and improve the water conditions of aboveground parts, then to promote growth. Under salt stress, $S$. heteroptera maintains relatively stable of $\mathrm{K}^{+}$and $\mathrm{Ca}^{2+}$ in the leaves, meanwhile increases the selective absorption of $\mathrm{K}^{+}$in root, thus ensure the required concentration of plant metabolism. For another, it accumulates lots of ions $\left(\mathrm{Na}^{+}, \mathrm{Cl}^{-}\right)$in the leaves, meanwhile adjusts the balance of $\mathrm{Na}^{+}$and $\mathrm{Cl}^{-}$by growing fast or increasing succulence, and best meets the needs of osmotic regulation without producing ions poison. This may be the regulating mechanism of $S$. heteroptera under salt stress.

\section{Soil Remediation}

\subsection{Salt-affected Soil}

S. heteroptera can absorb salts from saline soils and accumulate them within the plant tissue to significantly decrease the salt content. At a density of 15 plants $\mathrm{m}^{-2}, S$. heteroptera can potentially remove more than $3000 \mathrm{k} \mathrm{Na}^{+} \mathrm{ha}^{-1}$ from saline soil, suggesting that it can be used to improve the quality of saline soils (Zhao 1991). The improving function displays in improving soil structure, reducing soil salinity, increasing soil porosity, increasing the content of soil organic matter and total nitrogen and improving the soil biological activity significantly. Lin and the others (2005) reported the bioremediation of coastal saline soil in the Tianjin estuarine area by planting Suaeda salsa. The electric conductivity, content of organic matter and microbial amount of soil were compared. The result showed that the electric conductivity had decreased by $13 \%$; the organic matter and total nitrogen had increased by $43 \%$ and 18 ; the microbial amounts had increased, which indicated that the S.salsa had remarkable effects for improving the saline soil.

\subsection{Heavy Metal Polluted Soil}

S. heteroptera is a potentially suitable heavy-metal biomonitor and applicable for the phytoremediation of heavy metal polluted soil. Due to the anthropogenic activities in recent decades, heavy metal contaminants such as $\mathrm{Cd}, \mathrm{Pb}, \mathrm{Cu}$ and $\mathrm{Zn}$ have become a serious threat to water and soil ecosystems because of the persistent nature, long distance transport, and adverse effects of heavy metals to organisms. S. heteroptera has a high capacity of heavy metal accumulation and significantly reduces the levels of toxic metals from saline soils. Accumulation of $\mathrm{Cd}, \mathrm{Pb}, \mathrm{Cu}$ and $\mathrm{Zn}$ in the plant was studied. $\mathrm{Zhu}$ and the others (2005) 
reported that the plant had more obvious accumulation above four heavy metals in different tidelands, and the contents in sequence were $\mathrm{Zn}>\mathrm{Pb}>\mathrm{Cu}>\mathrm{Cd}$. The accumulation contents had the remarkable distinction in different parts of the plant owing to the selective tolerance to heavy metals of the plant. Contents of $\mathrm{Cu}$ in the plant were root>stem>leaf, $\mathrm{Zn}$ Leaf $>$ root $>$ stem, $\mathrm{Pb}$ root $>$ leaf $>$ stem and $\mathrm{Cd}$ root $>$ stem $\approx$ leaf ( $Z$ hu et al. 2005).

\subsection{Petroleum Hydrocarbon Contaminated Soil}

S. heteroptera has certain restoration effect on saline soil which is contaminated by petroleum hydrocarbon. It can help to reduce the oil polluted to the soil. Phytoremediation for the saline soil polluted by oil with $S$. heteroptera is a low-cost and effective strategy, and it also can be used in the remediation of large-scale contamination. Planting S. heteroptera can gradually eliminate the harm of petroleum hydrocarbon in saline soil, which is conductive to the restoration of coastal zone ecosystem (Xu et al., 2007).

\section{Population Degradation}

Degeneration mechanism research of $S$. heteroptera wetland was studied. Salt is an important factor influencing the degradation. When the soluble salt content was higher than $16 \mathrm{~g} \mathrm{~kg}^{-1}, S$. heteroptera would grow slowly, or even die; when the soil salt was less than $10 \mathrm{~g} \mathrm{~kg}^{-1}, S$. heteroptera could grow, but some plants appeared green in spring and summer. The nitrogen and phosphor and organic nutrition of plant, and organic matter of soil is the important source of mineral and organic nutrition of plant .In four different types of wetland, the nitrogen, phosphor and organic matter contents were all at low level, but the growth status in four types of wetland were different greatly, which indicated that the nutrients in soil was not the reason of the degeneration. Wang and the others (2010) reported that comparing the flourishing wetland to degenerating wetland, the flourishing wetland was submerged by diurnal tide everyday, the soluble salt content in soil was effected by tide, and the salinity in tide changed smoothly, while the degenerating wetland is submerged only by spring tide. The repeated dipping of tide avoids the salt accumulation in soil because of evaporation. So water is another important reason that causes $S$. heteroptera wetland degenerate. Many researches have shown that human activity is the key factor that causes $S$. heteroptera wetland degenerate, such as the building of dam, shrimp pond and road. These activities occupied directory $S$. heteroptera wetland and make the acreage of S.heteroptera wetland decrease (Wang et al., 2010).

\section{Planting and Breeding Technology}

\subsection{Soil Preparation}

The range of soil salinity that $S$. heteroptera adapted to is very wide. Sandy soil contained saline is advisable. The optimum $\mathrm{pH}$ is $8-8.5$. Select field and rake the land to be $1.2 \mathrm{~m}$ wide. Each $667 \mathrm{~m}^{2}$ is fertilized with $2500 \mathrm{~kg}$ organic fertilizer before sowing. Irrigate the land with enough water.

\subsection{Seed Collection}

At the end of October, most of the seeds are mature. Harvest and dry the plant then choose good ones from the seeds.

\subsection{Sowing}

Soak the seeds $6-8 \mathrm{~h}$ before sowing to promote the germination. Seeds of $S$. heteroptera germinate in late April, plants flower from July onwards, while seeds start to mature in late 
October and die in late November. Therefore, outdoor sowing is conducted from late March to early April. Due to its small seeds, thousand seed weight is $2.7 \mathrm{~g}$, sow $1000-2000 \mathrm{~g}$ seeds per $667 \mathrm{~m}^{2}$.

\subsection{Field Management}

Spray the herbicide before sowing to reduce weeds and avoid hurting the roots of seedlings by pulling weeds.

\subsection{Periodic Detection}

Periodic detection is conducted in planting areas. Record the density, biomass, plant height and the other indicators.

\subsection{Harvest}

The optimum harvesting time of S.heteroptera is when its new shoots grow to $20-25 \mathrm{~cm}$.

Zhao and the others reported the high frequency adventitious shoot induction and plantlet regeneration from immature inflorescence explants of $S$. heteroptera. Adventitious shoots were induced from immature inflorescence cultured on Murashige and Skoog (MS) medium supplemented with $1.0 \mathrm{mg} \cdot \mathrm{L}^{-1}$ 6-benzylaminopurine $\quad(6-\mathrm{BA})$ and $0.4 \mathrm{mg} \cdot \mathrm{L}^{-1}$ indole-3-aceticacid (IAA) for 25 days. Adventitious shoots were further multiplied vigorously and maintained for a long time on the same medium for adventitious shoot induction. Rooting was achieved on MS medium without any plant growth regulators after adventitious shoot was transplanted for 2-3 weeks (Zhao et al. 2006).

\section{Development Prospect and Significance}

\subsection{Agricultural Sustainable Development}

With the development of industrialized production and increase of population in our country, arable land area declines sharply. The unreasonable irrigation caused lots of secondary salinization of the fields. Excess salt in soil may inhibit the growth of most plants, thus limiting the crop yield. Accordingly, how to exploit and make use of a large area of salinization land while reducing the secondary salinization of soil and increasing the crop production is what our agricultural production has to solve in urgently. S. heteroptera growing in saline soil can absorb and accumulate considerable amounts of salt within the plant, thereby decreasing the salt content of the soil. Planting a large area of $S$. heteroptera in wasteland not only greatly increases production but also can make good use of wasteland and saline soil to produce high-quality food and edible raw materials. The development and utilization of $S$. heteroptera contribute greatly to the development of ecological agriculture. Therefore, $S$. heteroptera possesses a great significance to the agricultural sustainable development in the future.

\subsection{Protect Fresh Water}

Water resource shortage is one of the problems that affect human being, and China is one of 13 countries with serious water lack all over the world, while the traditional agriculture depends greatly on fresh water, which becomes the main contradiction of agricultural development. In traditional agriculture, higher-paying salt-leaching works are used. Conventional crops are planted after the soil ameliorating. The traditional agriculture is limited by fresh water resources shortage. There is an abundant seawater resource and underground salt water in our country, but these resources can not be used for traditional 
agriculture. S. heteroptera can be irrigated with seawater or underground water, and the contents of fat, protein, vitamin, minerals and trace elements are rich. We can make good use of its own unique character instead of higher-paying salt-leaching works, thus not only conserves fresh water resources but also makes it become a salt-tolerant economic crop and will provide experience and a basis for seawater irrigating agriculture.

\subsection{Maintain Ecological Environment}

All kinds of wetland in China with a total area of 66 million hectares, account for $10 \%$ of the world's total wetland area. Cui and the others (2008) reported that the high soil salinity is the key environmental factor for the degradation of wetland due to the inhibition of plant growth caused by salinity in Yellow River Delta (Cui et al. 2008). Due to its characteristics of shorter plant growth period, greater biomass and convenient harvest, $S$. heteroptera has a certain significance of improving and increasing the wetland's ecological environmental quality. $S$. heteroptera grows on tidal flat as a pioneer plant and its growth increases the composition of the organic matter in coastal saline soil and makes the salinity reduce gradually and then creates conditions for the growth of wetland plant. Currently, a quarter of China is desert, an area that is expanding by around 5000 square kilometers a year. S. heteroptera is an important sand-fixation plant. Planting a large area of $S$. heteroptera can make the sand dune fixed to prevent the migration of desert. S. heteroptera also plays an important role for the reclamation of desert areas.

S. heteroptera is an important material of forage, food, medicine, chemistry and industry. It not only can regulate soil environment, but also can provide considerable amounts of biomass. Planting $S$. heteroptera in saline soil and making them grow naturally will be able to obtain good economic benefit and ecological benefit. We work in the future not only should strengthen the research in the mechanism of salt tolerance and the effect of saline soil improvement, but also should expand its utilization range and maximize its potential values.

\section{References}

Askaril, H., Edqvist, J., Hajheidaril, M., Kafi, M., \& Salekdeh, G. H. (2006). Effects of salinity levels on proteome of Suaeda aegyptiaca leaes. Proteomics, 6, 2542-2554. http://dx.doi.org/10.1002/pmic.200500328

Cui, B. S., He, Q., \& Xhao, X. S. (2008). Ecological thresholds of Suaeda salsa to the environmental gradients of water table depth and soil salinity. Acta Ecol Sin, 28, 1408-1418. http://dx.doi.org/10.1016/S1872-2032(08)60050-5

Cui, H., \& Ji, J. (2009). Research status on suaeda salsa. Tianjin Agricultural Sciences, 15(4), 13-16.

Dendooven, L., Alcantara-Hernandez, R. J., Valenzuela-Encinas, C., Luna-Guido, M., Perez-Guevara, F., \& Marsch, R. (2010). Dynamics of carbon and nitrogen in an extreme alkaline saline soil : a review. Soil Biol Biochem, 42, 865-877. http://dx.doi.org/10.1016/j.soilbio.2010.02.014

Evelin, H., Kapoor, R., \& Giri, B. (2009). Arbscular mycorrhizal fungi in alleviation of salt stress: a review. Ann. Bot., 104, 1263-1280. http://dx.doi.org/10.1093/aob/mcp251

Jia, D. L., \& Liu, Y. C. (1977). Improvement of saline soil in the Yellow, Huai and Hai Rivers (p. 336). Beijing: Agriculture Publishing House. 
Kefu, Z., Hai, F., \& Ungar, I. A. (2002). Survey of halophyte species in China. Plant Sci., 163, 491-8. http://dx.doi.org/10.1016/S0168-9452(02)00160-7

Khan, M. A., \& Ungar, I. A. (1997). Effects of thermoperiod on recovery of seed germination of halophytes in saline conditions. J. Bot., 84, 279-283. http://dx.doi.org/10.2307/2446089

Khan, M. A., \& Weber, D. J. (Eds.) (2006). Ecophysiology of high salinity tolerant plants. Springer, Dordrecht. http://dx.doi.org/10.1007/1-4020-4018-0

Li, C., Liu, X., Yang, Y., \& Liu, C. (2005). The effects of saline condition on the germination and seedling growth of Suaeda salsa. Chinese Agriculture Science Bulletin, 21, 209-212.

Li, S., Li, J., Hu, X., Li, M., Yan, Z., Li, S., \& Fan, C. (2013). Study on enzymatic saccharification of Suaeda salsa as a new potential feedstock for bio-ethanol production. Journal of the Taiwan Institute of Chemical Engineers, 44, 904-910. http://dx.doi.org/10.1016/j.jtice.2013.02.004

Li, W., Liu, X., Khan, M. A., \& Yamaguchi, S. (2005). The effect of plant growth regulators, nitric oxide, nitrate, nitrite and light on the germination of dimorphic seed of Suaeda salsa under saline conditions. J. Plant Res., 118, 207-214. http://dx.doi.org/10.1007/s10265-005-0212-8

Li, W., Wang, D., Jin, T., Chang, Q., Yin, D., Xu, S., Liu, B., \& Liu, L. (2011). The vacuolar $\mathrm{Na}^{+} / \mathrm{H}^{+}$antiporter gene SsNHX1 from the halophyte salsola soda confers salt tolerance in transgenic alfalfa (Medicago sativa L.). Plant Mol Biol Rep, 29, 278-290. http://dx.doi.org/10.1007/s11105-010-0224-y

Li, X., Xiang, X., Zhou, J., Qu, B., \& Zhou, X. (2007). Advance of study on soil remediation and sewage treatment by halophyte suaeda salsa. Jiangsu Environmental Science and Technology, 20, 53-55.

Lin, X., Shen, J., Liu, K., \& Huang, X. (2005). Study on remediation dffects of Suaeda salsa L.planting on coastal saline soil. Advances in marine science, 23, 65-69.

Maggio, A., Barbieri, G., Raimondi, G., \& De Pascale, S. (2010). Contrasting effects of $\mathrm{GA}_{3}$ treatments on tomato plants exposed to increasing salinity. J Plant Growth Regul, 29, 63-72. http://dx.doi.org/10.1007/s00344-009-9114-7

Munns, R. (2002). Comparative physiology of salt and water stress. Plant Cell Environ, 25, 239-250. http://dx.doi.org/10.1046/j.0016-8025.2001.00808.x

Munns, R. (2005). Genes and salt tolerance: bringing them together. New Phytol, 167, 645-663. http://dx.doi.org/10.1111/j.1469-8137.2005.01487.x

Owojori, O. J., Reinecke, A. J., \& Rozanov, A. B. (2008). Effects of salinity on partitioning, uptake and toxicity of zinc in the earthworm Eisenia fetida. Soil Biohem, 40, 2385-2393. http://dx.doi.org/10.1016/j.soilbio.2008.05.019

Shao, G., Chen, M., Wang, W., \& Zhang, G. (2008). The effect of salinity pretreatment on Cd accumulation and Cd-induced stress in BADH-transgenic and nontransgenic rice seedlings. $J$ Plant Growth Regul, 27, 205-210. http://dx.doi.org/10.1007/s00344-008-9047-6

Short, D. C., \& Colmer, T. D. (1999). Salt tolerance in the halophyte Halosarcia pergranulata subsp.pergranulata. Ann. Bot., 83, 207-213. http://dx.doi.org/10.1006/anbo.1998.0812 
Sonjak, S., Udovic, M., Wraber, T., Likar, M., \& Marjana Regvar, M. (2009). Diversity of halophytes and identification of arbuscular mycorrhizal fungi colonizing their roots in an abandoned and sustained part of Secovlje salterns. Soil Biol Biochem, 41, 1847-1856. http://dx.doi.org/10.1016/j.soilbio.2009.06.006

Tessier, M., Gloaguen, J. C., \& Lefeuvre, J. C. (2000). Factors affecting the population dynamics of Suaeda maritime at initial stages of development. Plant Ecol., 147, 193-203. http://dx.doi.org/10.1023/A:1009854204841

Tsonev, T. D., Lazova, G. N., Stoinova, Z. G., \& Popova, L. P. (1998). A possible role for jasmonic acid in adaptation of barley seedlings to salinity stress. J Plant Growth Regul, 17, 153-159. http://dx.doi.org/10.1007/PL00007029

Ungar, I. A. (1996). Effects of salinity on seed germination, growth, and ion accumulation of Atriplex patula (Chenopodiaceae). Am. J. Bot., 83, 604-607. http://dx.doi.org/10.2307/2445919

Wang, C. Q., Chen, M., \& Wang, B. S. (2007). Betacyanin accumulation in the leaves of C3 halophyte Suaeda salsa L. is induced by watering roots with $\mathrm{H}_{2} \mathrm{O}_{2}$. Plant Sci., 172, 1-7. http://dx.doi.org/10.1016/j.plantsci.2006.06.015

Wang, Y., Liu, R., Gao, H., Bai, J., \& Ling, M. (2010). Degeneration mechanism research of Suaeda heteroptera wetland of the Shuangtaizi Estuary National Nature Reserve in China. Procedia Environmental Sciences, $\quad 2, \quad 1157-1162$. http://dx.doi.org/10.1016/j.proenv.2010.10.124

Wang, Z. (Ed.) (1993). Saline soils in China. Bejing: China Sci. Press.

Xu, C., Liu, X., Liu, Z., Wang, J., Jiang, Z., \& Cao, J. (2007). Remedial effect of Suaeda salsa (L.) Pall. Planting on the oil-polluted coastal zones. Journal of Safety and Environment, 7(1), 37-39.

Yang, G., Zhou, R., Tang, T., Chen, X., Ouyang, J., He, L., Li, W., Chen, S., Guo, M., Li, X., Zhong, C., \& Shi, S. (2011). Gene expression profiles in response to salt stress in Hibiscus tiliaceus. Plant Mol Biol Rep, 29, 609-617. http://dx.doi.org/10.1007/s11105-010-0267-0

Zhang, H. (2002). A study on the characters of content of inorganic ions in salt-stressed Suaeda salsa. Acta Bot Boreal-Occident. Sin., 22(1), 129-135.

Zhang, J. T., Zhang, Y., Du, Y. Y., Chen, S. Y., \& Tang, H. R. (2011). Dynamic metabonomic responses of tobacco (Nicotiana tabacum) plants to salt stress. J Proteome Res, 10, 1904-1914. http://dx.doi.org/10.1021/pr101140n

Zhang, L., Xu, H., \& Zhao, G. (2007). Salt tolerance of Suaeda salas and its soil ameliorating effect on coastal saline soil. Soils, 39(2), 310-313.

Zhao, K. F. (1991). Desalinization of saline soils by Suaeda salsa. Plant Soil, 135, 303-305. http://dx.doi.org/10.1007/BF00010921

Zhao, K. F. (1998). The Halophytes in China. Beijing: Science Press of China.

Zhao, S., Ruan, Y., \& Wang, B. (2006). Tissue culture and plant regeneration from immature inflorescence explants of Suaeda salsa. Chinese Bulletin of Botany, 23(1), 52-55. 


\section{Macrothink}

Aquatic Science and Technology

ISSN 2168-9148 2015, Vol. 3, No. 2

Zhu, M., Ding, Y., Zheng, D., Tao, P., J Yunxiu, Cui, Y., Gong, W., \& Ding, D. (2005). Accumulation and tolerance of $\mathrm{Cu}, \mathrm{Zn}, \mathrm{Pb}$ and $\mathrm{Cd}$ in plant Suaeda heteroptera Kitag in tideland. Marine Environmental Science, 24, 13-16.

\section{Copyright Disclaimer}

Copyright for this article is retained by the author(s), with first publication rights granted to the journal.

This is an open-access article distributed under the terms and conditions of the Creative Commons Attribution license (http://creativecommons.org/licenses/by/3.0/). 